\title{
Ragawi Calculations in Javanese Culture
}

\section{Transforming the Context of Elementary Mathematics}

\author{
Neni Mariana \\ Universitas Negeri Surabaya \\ Surabaya, Indonesia \\ nenimariana@unesa.ac.id
}

\author{
Budiyono \\ Universitas Negeri Surabaya \\ Surabaya, Indonesia \\ budiyono@unesa.ac.id
}

\author{
Irma Widya Anggraini \\ Universitas Negeri Surabaya \\ Surabaya, Indonesia \\ irmaanggraini@mhs.unesa.ac.id
}

\author{
Heru Subrata \\ Universitas Negeri Surabaya \\ Surabaya, Indonesia \\ herusubrata@unesa.ac.id
}

\begin{abstract}
Culture should be a fundamental thing for every individual. Combining the culture with existing learning is one way to reintroduce the culture to the future generation. Simultaneously, it cannot only increase a proud of culture, but also it offers an innovative way in learning. As the largest tribe in Indonesia, Javanese culture needs to be reproduced through education and broader disseminated in other disciplines, mathematics is no exception. Meanwhile, emerging culture in mathematical concept has been conveyed by some experts in the study of ethnomathematics. Combining mathematics and Javanese culture is expected to provide a new breakthrough. The paradigm of this study lied on transformative research, which integrates multi-qualitative research paradigms through critical auto-ethnographical study. This paper aims to present a study on ethnomathematics and ragawi calculations discussed in depth through the point of view of the use of a numeric base. The rules and the origins of ethnomathematics, and the magnitude of conversions in the ragawi calculations are also explained as the research findings. Some examples of mathematical problems using ragawi calculations' context are provided to give insights for elementary mathematics educators in their classroom practices.
\end{abstract}

Keywords---elementary school; ethnomathematics; Javanese culture; ragawi calculations

\section{INTRODUCTION}

Indonesia is one of the archipelagic countries with diverse ethnic, custom, culture and beliefs in accordance with their respective territories. According to BPS data in 2010 which Javanese as the tribe with the largest population about $40.05 \%$ of the Indonesia population and the Sundanese $15.50 \%$ in the second position. With the figures reaching $96,244,737$ individuals or nearly one hundred million makes the Javanese had strong influenced the environment of Indonesian life which has diverse cultures and has been born for centuries. Culture, religion, and customs are closely related to human life, especially in the circumstances and the socialization. This certainly affects the ethics and mindset that the individual brought.
Education and culture control are a very important role in the effort to grow and develop the good value of a nation, and it will have an effect the formation of characters based on the good cultural values.

Mathematics was a human activity that can be attributed to real life. It is not as a finished product that the teachers give to the students, but a process that is constructed by the students based on their experience. It is time for mathematics to enter into the part of the students' based on the beliefs and culture that they have in which they grew up. Mathematics can provide content and bridges between daily activity based culture and beliefs. It seems real, reasonable, and easy to understand.

It is very possible that mathematics is incorporated into the social sciences that contribute to social and cultural fields, it is called as applied mathematics. It is a bridge between pure mathematics and the world of science and technology and science social. On the other hand, mathematics also has its own branch of the study in the social field especially in a culture called ethnomathematics. When culture, mathematics, and education are combined, it is called as ethnomathematics. Many societies have mathematical traditions and have developed a wide range of areas of mathematical thought. Ethnomatematics is a local-based approach to mathematics-based learning. It can provide content and bridge between daily mathematics in the world based on local culture with mathematics for school.

Therefore, the authors try to dig some Javanese culture related to mathematics, especially it can be applied in the elementary level. Some concepts of mathematics can be applied in primary school learning are ethnomathematics and ragawi calculations. They are suitable with the background of elementary school's mathematics that is the matter of number and measurement operations. This becomes interesting because the authors ever experienced when being the students of a primary school that the culture of Javanese 
and mathematics are two different things. Through the learning of mathematics that integrated with Javanese culture, it might increase the students' interest in culture.

\section{METHOD}

This research will be an example of transformative research which not only focuses on solving research problems, but also involves the writers as the novice in depth study and the practice of professional world of researchers [1].

\section{A. Paradigm}

This research using postmodern paradigm approach that is able to represent research about culture. It talks about ethno and uses writing as one of its methods. Besides, it carries the concept of "representation" as the most important thing. In the postmodern paradigm, Denzin and Lincoln [2] state that nothing can connect with the surrounding directly, especially between the thoughts and feeling, except by communicating. It means not every people's feeling can be communicated. Sometimes, the emotion and the problem are difficult to express. Therefore, postmodern paradigm provides a method that might help people to express their perspectives through languages. Various kinds of communication can express people's feeling, prespective, and ideas, for instance language arts (poetry, story, script of a drama), dance, art, and gesture. On the other hand, this paradigm expresses a strong moral of relativism by reducing the notion of universalism and embracing the postmodern constructive, especially the cultural's studies with pluralism as their main principle [1].

\section{B. Method}

The method used is the study of documents and literature. It examines and assess in detailed either ontology or epistemology. In this study, the review of document and literature will cover the literature sources, for example the books that support learning of mathematics in Javanese culture, historical archives, and curriculum in Indonesia.

\section{Data Analysis}

The data analysis technique used in transformative research is frame of reference. Each data must have a very strong interconnection with each other. Frame of reference is more inclusive, discriminative, self-reflective, and experienced that are integrated with each other. Frame of reference consists of cognitive, conative, and emotional. It consists of two dimensions which are habit of mind and point of view. In order to make the data analysis clearer and equal, the researchers have the "reduction" processes that include, (1) completing, (2) simplifying, (3) focusing, (4) doing abstraction, and (5) transforming data continuous.

\section{Quality Standarts}

This research uses 2 quality standarts, which are

1) Trustworthiness and Authenticity

The elements of trust that will be included in this study include credibility, transferability, dependency, conformability the data, and data of interview which includes number of speakers, time, place and transcript of the interview. The record of profiling and assessing the data will be stored as a proof when needed for confirming [3].

The element of authenticity will be addressed the document's sources used in this research. Besides, the researchers covers the relationship between the people involved and the researchers. Where the authenticity is in the form of a writer's learning in understanding his role as an educator as well as others who are in charge of doing his professional duties as a student.

2) Praxis

Praxis is one of the quality standards in postmodern paradigm research. It concerns the procedure how the researchers try to stimulate the readers in taking deliberate action to change the behavior patterns. It is not only selfevaluation, but also it is a process of learning and bridging for the readers. The results of the researchers' experience will be developed exploratively to the surrounding that affects the issues raised. Furthermore, the data will be processed in an investigation, while it is returned to the researchers [4]. It becomes an absolute standard of research quality that the research which is adopted belongs to the transformative research.

\section{RESULTS}

In the tradition of Javanese culture, it has a kejawen calculation. The calculation is usually based on days and pasaran. This is called as the etnomathic or etnomatemathics. Etnomathic appears because of the social conditions associated with community's trust and order.

Ethnomathematics is a form of mathematical integration into a culture. Its aim is to solve the problems that are mysterious or considered to be trust by counting the natural numbers in order to know the truth of life. Then, ethnomathematics becomes a basic thing in the community because of the complexity and the variation of the counting operations.

In Javanese culture, every detail of life that regulates human activity is considered seriously, for example setting up a house. Javanese has its own traditions or calculations, they belive that goodness will come if everything starts well, for example founding the house. Many aspects in Javanese calculations should be determined, for instance a house's location and direction, the best day to build up, or the door's setting. Moreover, this calculation begins with the determination of the house's direction, then how to measure the house's parts that is adapted to the owner's body through ragawi calculations. Furthermore, similar cases like the example before will be examined more in depth. They are transformed into the learning of mathematics in the elementary school. Table I. below is a sample about the rules of Javanese calculations using the concept of days and pasaran.

This is a table of days that Javanese people were used to make a calculation. 
TABLE I. TABLE OF DAYS AND VALUE OF NUMBERS

\begin{tabular}{|l|l|c|}
\hline No. & \multicolumn{1}{|c|}{ Name of days } & Value of numbers \\
\hline 1. & Ahad/Akad/Sunday & 5 \\
\hline 2. & Senen/Monday & 3 \\
\hline 3. & Seloso/ Tuesday & 7 \\
\hline 4. & Rebo/Wednesday & 8 \\
\hline 5. & Kemis/ Thursday & 6 \\
\hline 6. & Jumuah/Friday & 9 \\
\hline 7. & Setu/Saturday & \\
\hline
\end{tabular}

Table II. below is a table of pasaran that Javanese people were used to make a calculations.

TABLE II. TABLE OF PASARAN AND VALUE OF NUMBERS

\begin{tabular}{|l|l|c|}
\hline No. & \multicolumn{1}{|c|}{ Name of pasaran } & Value of numbers \\
\hline 1. & Kliwon & 8 \\
\hline 2. & Legi & 5 \\
\hline 3. & Pahing & 9 \\
\hline 4. & Pon & 7 \\
\hline 5. & Wage & \\
\hline
\end{tabular}

There is a procedure how to calculate according to the day table and the pasaran table, for example Sunday Pon. Then, Sunday is worth 5 and Pon is 7, then Sunday Pon means $5+$ $7=12$.

Furthermore, the rule in determining the direction of building a house can calculate by summing up the number of days and the pasaran of the house owner's birth with the provisions below:

7 is good if it goes north or east.

8 is good if it goes north or east.

9 is good if it goes south or east.

10 is good if it goes south or west.

11 is good if you go to the west.

12 is good if it goes north or west.

13 is good if it goes north or east.

14 is good to go south or east.

15 is good if it goes to the west.

16 is good if it goes to the west.

17 is good to go north or west.

18 is good if it goes north or east.

From the data above, it can be assumed that if the house's owner was born on Saturday Pahing, a good house faces north or east. It is because the value number of days and pasaran table show that Saturday is 9 and Pahing is 9. Then, the worth of Saturday Pahing is $9+9=18$.

Equally important, there is the term pekan or peken which comes from the word pkan means pasaran (market). This term refers to the date of trade in the market which is carried out every 5 days. In general, the most crowded day is Legi. The term pekan also means 5 and one pekan means 5 days.
Thus, there are 5 days that are used in trading market. Furthermore, those five days are named Legi/Manis, Pahing/Jenar, Pon/Palguna, Wage/Kresna/Langking, and Kliwon/Kasih. These five days are called pancawara. The cycle of pancawara is called the pekan/pasaran. In addition, Javanese calculation is used pasaran since market is a fundamental concept and a supporter of Javanese calculations. Every name of the days are always paired with the name of pasaran.

Besides ethnomathematics, Javanese society also uses ragawi calculations in daily life. The researchers have an experience as the example, ragawi calculations are often used in calculating in building a house, for instance the height or width of the door. In consequence, the built house will be in accordance with the size of the owner's body. This has the value of its own privileges since it uses owner's physical size. The house can comfort the owner since the size is in accordance with the host's posture. The use of this physical size indicates that space is the evidence and representation of its owner.

In addition, the determination of house's direction in the Javanese tradition also regulates the placement of the door's position as well as the size used. The measurement used in the house's construction usually uses raga (body) as its benchmark. Therefore, it is known for horizontal measurement, for example kilan, nyari (thumb), hasta, depa, pecak (footprint), foot, tumbak (ru), and tebah. Next is for the vertical/upright size is sakpenge (awean) and sakdedeg (dedeg). The measurement refers to the body which is commonly called as ragawi calculations.

The constants of harmony in the physical bodies can be written mathematically into $5 \mathrm{x}+\mathrm{n}$, with $\mathrm{x}$ is called the multiplier of count and $\mathrm{n}$ is the determiner of constant, for example $0,1,2,3$, and 4 . Incase of praxis, the determinant constants of $\mathrm{n}$ for $5 \mathrm{x}+\mathrm{n}$ are $\mathrm{n}=1,2,3,4$, and 5 , without 0 . The interesting thing about physical measurement is the use of the base number in it. The example is 1 depa $=4$ hasta $=$ 8 kilan $=1 / 8$ depa and 1 hasta $=1 / 4$ depa , no more and no less.

Table III. below is the conversion for ragawi calculations.

TABLE III. CONVERSION OF RAGAWI CALCULATIONS

\begin{tabular}{|c|l|c|l|}
\hline No & \multicolumn{1}{|c|}{ Measure } & Picture & Conversion \\
\hline 1. & $\begin{array}{l}\text { Jempol/Nyari } \\
\text { Wide thumb }\end{array}$ & $\begin{array}{l}1 \text { jempol }= \\
\pm 2,6 \mathrm{~cm}\end{array}$ \\
\hline 2. & $\begin{array}{l}\text { Tebah } \\
\text { Width of palms }\end{array}$ & $\begin{array}{l}\text { Cengkang } \\
\text { The distance between } \\
\text { the tip of the thumb and } \\
\text { the tip of the index } \\
\text { finger when the fingers } \\
\text { are stretched }\end{array}$ & $\begin{array}{l}1 \text { tebah } \\
\pm 9 \mathrm{~cm}\end{array}$ \\
\hline 3. & & $\begin{array}{l} \pm 13,5 \mathrm{~cm}- \\
16,5 \mathrm{~cm}\end{array}$ \\
\hline
\end{tabular}




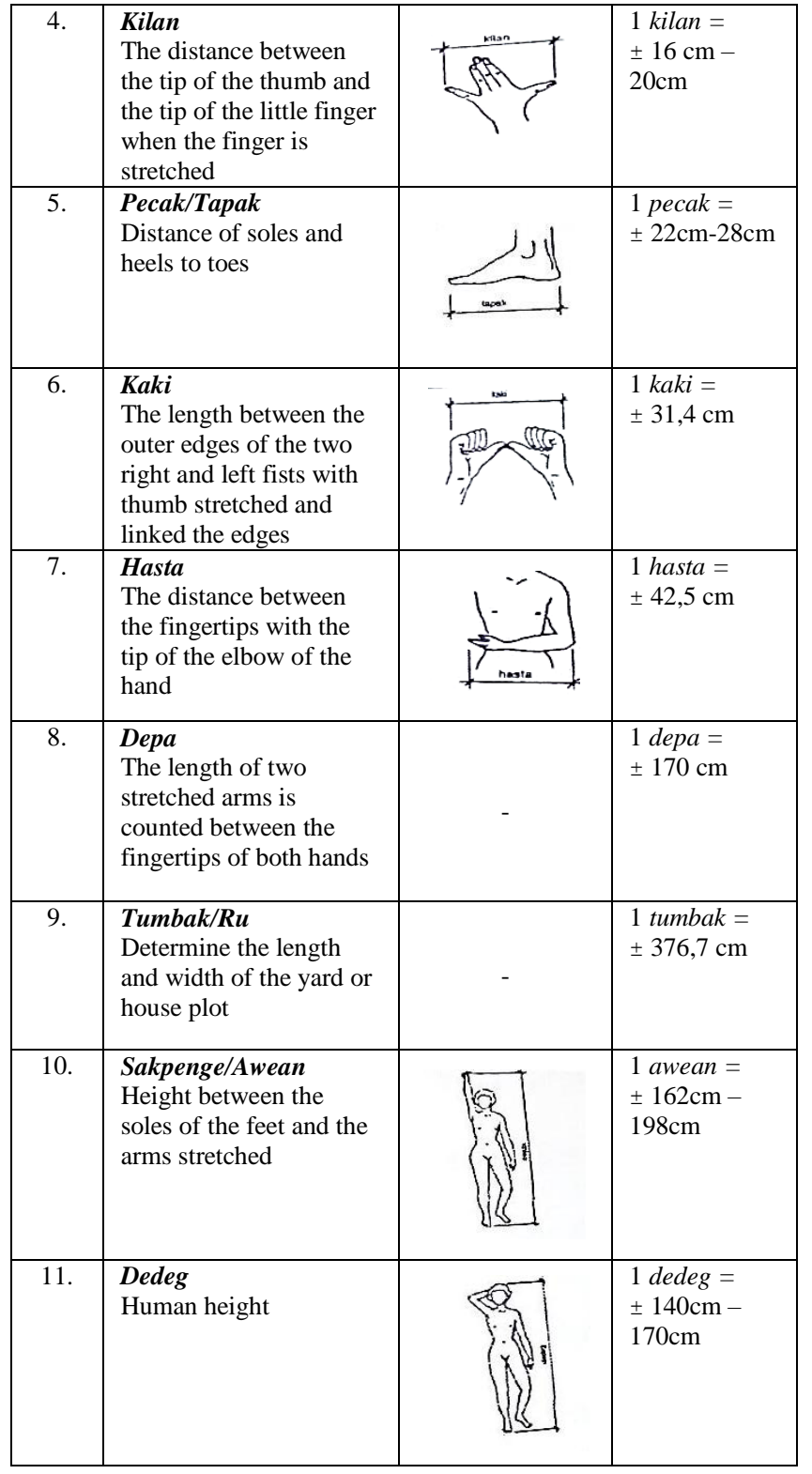

In the calculation of Javanese, mathematics usually uses base number of 10 . In addition, basic number of 10 is used in islamic spiritual tradition and physical measurement. The example in physical measurements is 1 tapak $=10^{1} \mathrm{jempol}$. It means that $10^{0}$ used the term of jempol, while $10^{1}$ is tapak. It is applied as well as on vertical size (upright) that is 1 dedeg $=10$ cengkang

\section{DISCUSSION}

Through the results of the exploration of existing literature, it found several concepts of Javanese calculations that can be integrated in Primary School's learning, for example the sum of the use of base number 5 on the pasaran calculation, the operation of addition and measurement using the ragawi calculations.

Contextual transformation in mathematics learning can be through various ways, for example

\section{1) Through learning activities}

Learning activities that can be done in a classroom is before teaching of the standard unit. First, the teachers can teach the students measurements using ragawi calculations. Then, the use of it is well suited to the early grader of the students. Besides, the classroom could be used as the object of measurement.

2) By using Javanese calculation of the cycles number of 5 in Elementary Mathematics

The application of Javanese calculations on elementary mathematics, especially in pasaran calculations, can be used in counting with the cycle number of 5 . Cycle number 5 can be used to calculate the fast way.

The most commonly used is the concept of counting the numbers $\{5,10,15,20,25,30,35 \ldots\}$ which is often used in simple sum operation. It is because the students can sum up by adding the palms of their hands ( 5 fingers). In addition, the base 5 can be used in calculating multiplication and squared suffix 5 in a fast way, for example

The $1^{\text {st }}$ example: $15^{2}$
$\mathbf{1 5}^{\mathbf{2}}=(1 \mathrm{x}(1+1)) \& 25=(1 \times 2) \& 25=225$
The $2^{\text {nd }}$ example: $45^{2}$
$\mathbf{4 5}^{\mathbf{2}}=(4 \mathrm{x}(4+1)) \& 25=(4 \times 5) \& 25=2025$
*only for number suffix 5

\section{CONCLUSION}

Ethnomathematics became a very basic thing to the community because they recognize the first complex count operation on it. Ethnomathematics and ragawi calculation are part of Javanese culture that contain many concepts of mathematics. It is in accordance with learning mathematics in primary school that related to the measurement and number operations. This is a realistic learning that students can use in their mathematics learning.

Then, etnomathematics found the concept of base number 5 and on the ragawi calculation found the base number 10 or the concept of fractions. For ragawi calculations, it can be used in active early grade mathematics learning. It involves a lot of students' activities in trying and exploring their surrounding school area.

It is time to promote how to integrate Javanese culture with mathematics learning in elementary school by increasing the study Javanese culture. Therefore, Javanese culture is not only considered a mystical. It can illustrate that Javanese culture also has a reasonable mathematical explanation and can be drafted for inclusion into mathematics learning. Through this procedure, prospective teachers can increase the students' proud of their culture. Besides, the researchers can examine the concept that existed in the Javanese culture for the next level.

\section{ACKNOWLEDGMENT}

The authors want to present a big thankfulness to Universitas Negeri Surabaya which facilitates the research and the conference in a hand. 


\section{REFERENCES}

[1] P. C. Taylor, E. Taylor, and B. C. Luitel, "Multi-paradigmatic transformative research as/for teacher education: An integral perspective," Second international handbook of science education., vol. 27, no. 4, pp. 373-387, 2012.

[2] N. K. Denzin and Y. S. Lincoln, "Introduction: the discipline and practice of qualitative research," in The sage handbook of qualitative research., 2005

[3] E. Guba and Y. Lincoln, "Guba, Lincoln (1989) Fourth Generation Evaluation Foreword.pdf," in Fourth Generation Evaluation, 1989.

[4] J. W. Richardson, "Bird migration and wind Turbines : Migration timing, flight behavior and collision risk," Natl. avian, 2000. 